\title{
補腎剂による血管弛緩作用の 加齢変化と病態依存性
}

要約 : 東洋医学的概念, 五藏の「腎」は先天の生命力 を表し，老化予防・抗病力の賦活を意味する。更年期 症状, 冷え, 全身倦㤐, 水分代謝の機能低下, 頻尿, 夜 間頻尿, 尿失禁, 浮腫, 前立腺肥大, 性欲減退, 勃起 障害などの臨床症状を腎虚という。腎虚に対して処方

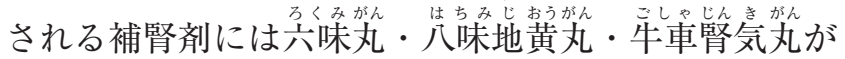
あり, 六味丸に 2 生薬ずつ添加した生薬構成をしてい る。補腎剤は若年ラット（10～15 週齢）と高齢ラット （35 週齢以上）で血管弛緩作用に違いを示した。単一 フィトケミカル（植物由来機能物質）では薬理効果の 加齢的減衰が著明であるが, 多成分複合薬（漢方薬を 含む）は抗加齢効果を表す. 六味丸は, 高齢ラットで は血管内皮依存性弛緩作用が弱くなった。高齢ラット で，八味地黄丸は六味丸より強い弛緩作用を表すが, 内皮依存性弛緩作用はみられず，平滑筋作用が強い. 牛車腎気丸は高齢ラットで弛緩作用は増強し, 血管内 皮依存性弛緩作用は保たれた。含有生薬の違い（種類， 含有数）から，薬理作用に加齢的差異が表れたと考え られた。一方, 糖尿病ラットでは, 血管弛緩作用の加
齢変化は著明に見られなかった，臨床適用では，長期 投与によって主訴症状を改善した。同時に圧脈波解析 では動脈スティフネス（CAVI）も著明に低下させた。 病態下では急性投与での効果発現は表れにくく, 長期 投与の必要性が示唆された。

\section{1.はじめに}

漢方医学は「気・血・水」「先綱弁証」「六病位」「五 蔵」などの弁証法から「証」が決定される(1)。この 「証」の中に, 病位, 病因, 病性, 邪気と正気との盛衰 などが包括されている。「八綱」とは，㓌・陽・表· 裏・寒・熱・虚・実を表し, 弁証論治の基礎となる. 図 1 に示すように，陰陽五行説とは「肝・心・脾・ 肺・腎」で個々の臟器機能だけを示すのではなく，た とえば「腎」は先天の生命力, 生まれながらの寿命を 決める生命バッテリーのことを意味する. 排尿機能, 生殖, 発育成長, 知能, 知覚, 運動, 耳, 老化, 寿命 を含んでいる. 加齢とは, 東洋医学では「五臓」の衰 退を意味し(2), とくに「腎」が重要な症を表す。

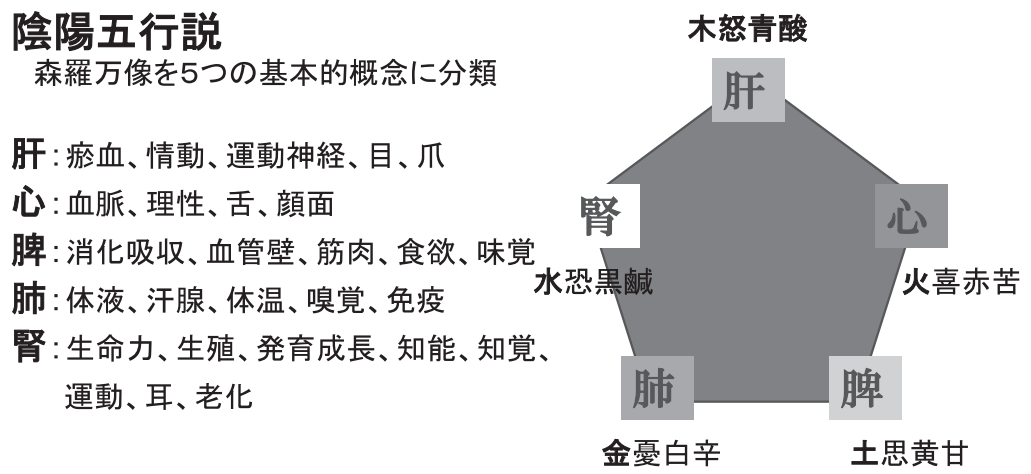

図 1 陰陽五行説

キーワード : 補腎剂, 六味丸, 八味地黄丸, 牛車腎気丸, 糖尿病ラット

1) 四天王寺大学 保健教育 (厂583-8501 大阪府羽曳野市学園前 3 丁目 2-1)

2) 郡山青藍病院 内科（７639-1136 奈良県大和郡山市本庄町 1-1）

3) 同志社女子大学 薬学部 創薬理論科学（６10-0395 京都府京田辺市興戸)

E-mail: hysat@shitennoji.ac.jp 原稿受領日：2015 年 12 月 11 日，依頼原稿

Title: Kampo pharmacology: modulation by Hojin formulations of age-dependent vasodilatation and the dependence of diseases

Author: Hiroyasu Satoh, Seiichiro Nishida, Katsuharu Tsuchida 
この「腎」の機能低下や障害を「腎虚」といい，加 齢に伴う症状で, 更年期症状, 冷え, 全身倦怠, 水分 代謝の機能低下, 頻尿, 夜間頻尿, 尿失禁, 浮腫, 前 立腺肥大, 性欲減退, 勃起障害などの症状がある。腎 虚に対して処方されるのが補腎剂であり，兵嗓丸妿， 几味地黄丸，㔖車腎気丸が㧝げられる。六味丸は 6 種 の生薬 (地黄, 山葉鿒, 山薬, 沢瀉, 获荅, 牲丹皮) から構成され，これに 2 生薬（桂皮と附子）を添加し たのが八味地黄丸である。牛車腎気丸はさらに 2 生薬 (军膝，車前子）を添加したもの（10 種生薬）である. したがって,よく類似しており, 補腎剤 3 処方の作用 を比較するには判りやすい.

六味丸は腎陽虚の方剤で，湿熱に対する清熱作用， 八味地黄丸は腎陰虚（一般的に高齢者）に適用される (3).八味地黄丸は, 加齢による頻尿や腰痛, 冷え, 口 渇等の治療に, また糖尿病性神経症 $(4,5)$, 前立腺肥大 （6）の治療にも適用される．牛車腎気丸は神経性しび れ, 疼痛を併発する症例に適用される (4)，2 種ずつ含 有生薬が添加され, その違いが薬理効果の差異を生ん でいると推測される.

\section{2. ラット大動脈の加齢依存性弛緩作用}

我々は補腎剤である六味丸, 八味地黄丸, 牛車腎気 丸の血管弛緩作用について既に報告している(7). 強 力な血管驰緩作用は末梢循環改善により，腎虚による 腰痛, 冷えやしびれの改善に効果を示すと考えられる.

若年ラット $(10 \sim 15$ 週齢) と高齢ラット（35 週齢以 上）の大動脈リング切片（3 mm）をマグヌス管（クレ ブス液) 内に固定し，血管緊張を比較した。 NE $(5 \mu \mathrm{M})$ で血管収縮させ, 六味丸（TJ-67, ッムラ), 八味地黄 丸（TJ-7），牛車腎気丸（TJ-107）エキス剂投与後，血 管弛緩作用の加齢的変化を調べた. 血管内皮の有無に よる差異も検討した。

3 方剂全て, 用量依存性の血管弛緩作用を示した. 六味丸は, $1 \mathrm{mg} / \mathrm{ml}$ で若年ラットは $28.7 \pm 2.7 \%(\mathrm{n}=8$, $P<0.01)$ ，高齢ラットで $18.9 \pm 4.4 \% （ \mathrm{n}=8, \quad P<0.05 ）$ と加齢により弛緩作用の減弱を認めた。血管内皮を 除去すると，若年ラットの血管弛緩作用は減弱したが, 高齢ラットでは影響は受けず， $18.0 \pm 4.8 \% （ \mathrm{n}=4$, $P<0.01)$ であった。 八味地黄丸 $(1 \mathrm{mg} / \mathrm{ml})$ は, 若年 ラットでは $33.9 \pm 4.5 \%(\mathrm{n}=8)$ であったが, 高齢ラッ トでは $31.9 \pm 5.7 \% （ \mathrm{n}=8, P<0.001 ）$ と, 六味丸より も強い弛緩作用を示した。内皮除去後でも影響はな かった．牛車腎気丸 $(1 \mathrm{mg} / \mathrm{ml})$ は若年ラットで, 24.7 $\pm 2.5 \% （ \mathrm{n}=8, P<0.01 ）$ であったが，高齢ラットでは $42 \pm 7.0 \% （ \mathrm{n}=8, P<0.001 ）$ とさらに強い弛緩作用を

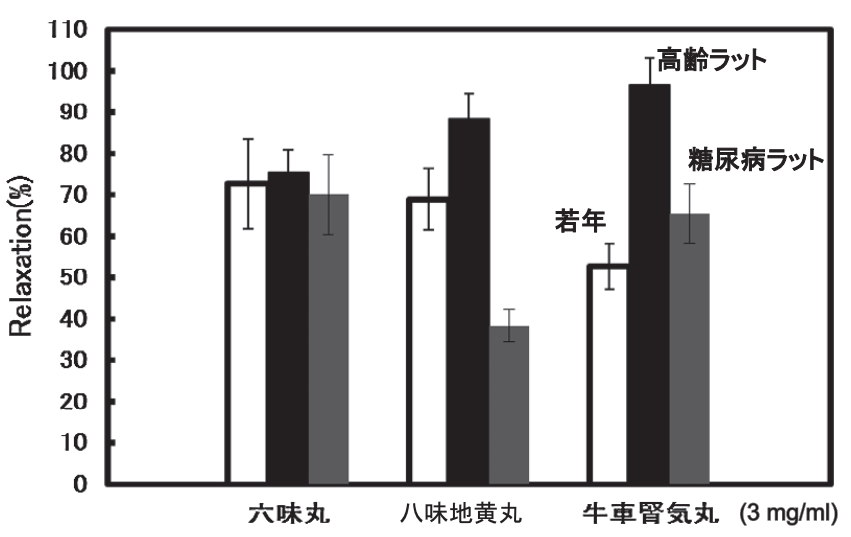

図 2 補腎㓮の血管弛緩作用の加齢性変化と糖尿病ラットとの比較 若年齢・高齢ラット, 糖尿病ラットの大動脈切片に, 各漢方薬 $3 \mathrm{mg} / \mathrm{ml}$ 投与での作用比較. 值は平均值土S.E.D.

示した．内皮除去では $34.3 \pm 7.0 \% （ \mathrm{n}=4, \quad P<0.001 ）$ に滅弱したが，強い作用を示した（図2）。

高齢ラットでは六味丸の弛緩作用は弱くなり, 内皮 依存性作用も認めなくなった，一般的に加齢依存性内 皮機能の低下が推測される. しかし, 高齢ラットで八 味地黄丸の弛緩作用は, 六味丸よりも強くなるものの, 内皮依存性作用は見られなかったので, 平滑筋への作 用が強くなっていると思われた，牛車腎気丸は，高齢 ラットでは弛緩作用は強くなり, 血管内皮依存性の弛 緩作用は変わらなかった。これら 3 方剤はよく似た生 薬構成をしているが, 含有生薬の違いから薬理作用の 差異を発生していると考えられる。しかし, 添加生薬 が引き起こす可能性だけでなく, 存在する生薬, フィ トケミカルと添加された生薬間の相互作用による可能 性も考えられる(8-10)。また, 糖尿病ラットは血管内 皮機能に組織的障害があると考えられるが, 血管内皮 性弛緩作用の加齢変化は明瞭ではなく, 内皮障害によ る加齢的減衰はなかった. 病態ラット（摘出血管）に 対して, 急性投与では漢方薬の効果発現は現れにくい のかも知れない.

このような結果より，3 種漢方補腎剂の弛緩作用の 違いは, 血管内皮細胞に対する作用は弱く, 平滑筋へ の作用 $\left(\mathrm{Ca}^{2+}\right.$ チャネル， $\beta$ 受容体，PK-C 依存性など $)$ による感受性の差によると考えられる（表 1).

\section{3. 動脈脈波解析}

血管病態変化の臨床評価法として, 昨今圧脈波解析 が実施されている. 上腕一足首間の脈波伝播速度 (brachial to ankle pulse wave velocity : baPWV) (11), もしくは CAVI (cardio-ankle vascular index) で臨床 検査されている (12). さらに, 足関節 ·上腕血圧比 (ankle brachial pressure index：ABI）では, 下肢動脈 
表 1 血管弛緩作用の機序

\begin{tabular}{|l|l|c|c|c|}
\hline & 薬理学的機序 & 六味丸 & 八味地黄丸 & 牛車腎気丸 \\
\hline \multirow{3}{*}{ 内皮細胞 } & $\mathrm{NO}$ 合成 & + & + & + \\
\cline { 2 - 5 } & $\mathrm{PGI}_{2}$ 合成 & - & - & - \\
\hline \multirow{3}{*}{ 血管平滑筋細胞 } & $\mathrm{Ca}^{2+}$ チャネル阻害作用 & + & + & + \\
\cline { 2 - 5 } & $\mathrm{PK}-\mathrm{C}$ 阻害作用 & + & + & + \\
\cline { 2 - 5 } & $\beta$ 受容体刺激作用 & - & + & + \\
\hline
\end{tabular}

狭窄の有無を予測することができる (13)，高齢者の冷 えやしびれを訴えるケースで, 動脈硬化による著しい 血流低下の有無を PWV や CAVI, ABI の測定によって 診断している.

我々は，最近開発されたデジタル自動血圧計を用い， 圧脈波形状から臨床評価もしている(14)。圧脈波は左 心室からの駆出波と末梢血管抵抗により反射して戻る 逆行性の圧波（反射波）との合体した形状で表わされ る. 加齢変化, 動脈硬化が進行するほど, 血管壁の トーヌスは増加し，反射波の波高が高くなり，またよ り速く反射して脈波形状に変化を与える. 駆出波と反 射波の波高比率を動脈硬化度 augmentation index (AI) として指標にしている. AI は血管側の特性単独で決 まるのではなく, 心臟側との相互作用, および脈波の 反射に関わる多くの因子が関与している．健常者ボラ ンティア $(\mathrm{n}=24)$ への八味地黄丸（TJ-7）頓服 $(2.5 \mathrm{~g})$ では， $\mathrm{AI}$ 変化は $+0.6 \pm 0.2 \%$ であり著明な効果は見ら れなかった。中血圧は $0.7 \pm 0.5 \%$ 低下した。 収縮 期・弛緩期血圧もあまり変化（1.4～0.8\%増加）せず, 心拍数は $5.6 \pm 0.9 \%$ 減少した。健常者に対する急性効 果は弱く，明らかな変化は見られなかった。

\section{4. 臨床効果}

臨床的に, 高齢者に八味地黄丸, 牛車腎気丸が多用 されている，頻尿や口の渴き，下肢のしびれなどに治 療効果を示す (表 2)。また, 図 3 に示すように, 両側
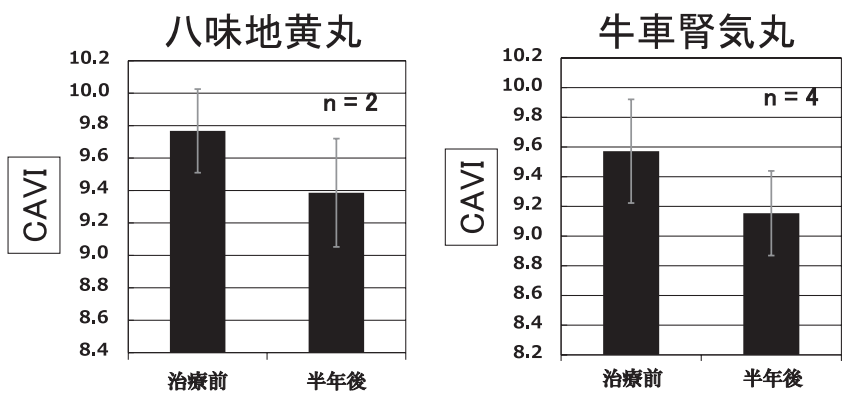

図 3 動脈硬化指標 CAVI の改善

值は, 左右両側の平均值士S.E.D. を示す. 全体の平均 $75.6 \pm 6.2$ 歳.

CAVI を低下させ, 末梢循環の血流改善効果を示した $(9,15)$.

症例 1：79 歳女性（身長 $150 \mathrm{~cm}$, 体重 $51 \mathrm{~kg}$ )。血圧 $118 / 60 \mathrm{mmHg}$, 心拍数 69 回 / 分. 主訴は舌の痛みと, 口腔の乾燥症, 全身倦急感であった。高血圧治療を受 けており， benidipine $4 \mathrm{mg}$ および， doxazosin $2 \mathrm{mg}$, rosuvastatin $2.5 \mathrm{mg}$ を内服. 八味地黄丸（TJ-7） $5 \mathrm{~g}$ 分 2 朝夕食間に変更した。 下肢のだるさはすみやかに消 失した，血流障害の有無の検査をすると，右側 $\mathrm{ABI}$ 1.22 , 左側 $\mathrm{ABI} 1.21$ と動脈の閉塞を疑わせる所見はな かったが, CAVI は右側 9.8, 左側 9.7 と高值で動脈硬 化の疑いがあった。 八味地黄丸投与後, 口腔乾燥は軽 減し, 舌の痛みも半減した. 4 力月後, CAVI は, 右側 9.1, 左側 8.9 まで低下した。 その後, 舌の痛みは消失 しなかったが，日常生活で痛みが気にならなくなった。

表 2 補腎剤の EBM 漢方薬理学

\begin{tabular}{|c|c|}
\hline $\begin{array}{l}\text { 薬理学的エビデンス } \\
\text { 科学知 薬理作用・作用機序 }\end{array}$ & $\begin{array}{c}\text { 臨床的エビデンス } \\
\text { 経験知 }\end{array}$ \\
\hline $\begin{array}{l}\text { (1)血管弛緩作用 } \\
\cdot \mathrm{Ca}^{2+} \text { チャル阻害 } \\
\cdot \beta \text { 受容体刺激 } \\
\cdot \text { PK-C 阻害 } \\
\text { (2)血液凝固阻止作用, 抗血栓作用 } \\
\text { (3) SOD 様活性 } \\
\text { (4)脂質改善代謝改善作用 } \\
\text { (5)糖代謝改善作用 } \\
\text { (6)利尿作用 } \\
\text { (7)腎障害改善作用 }\end{array}$ & $\begin{array}{l}\text { (1)動脈硬化改善 } \\
\text { (2)排尿障害 (頻尿, 多量の残尿) の改善 } \\
\text { (3)下肢の冷え (左下肢), しびれ改善 }\end{array}$ \\
\hline
\end{tabular}


症例 2：65 歳女性（身長 $152 \mathrm{~cm}$, 体重 $51 \mathrm{~kg}$ )。高脂 血症と高血圧で内科外来を通院中. 下肢の冷えとしび れと頻尿を主訴に受診した. 4 年間, cardesartan $2 \mathrm{mg}$, atorvastatin $10 \mathrm{mg}$ を服用していた。この 4 年 間の血圧とコレステロールは安定した数值を維持して いた。 八味地黄丸（TJ-7） $7.5 \mathrm{~g} /$ 日を投与開始, 半年間 服用で冷えは消失し，しびれは軽減した。また，夜間 頻尿も改善した. 動脈硬化指標となる CAVI は八味地 黄丸投与前, 右側 10.2, 左側 10.4 であったが, 1 年後, 右側 10.1, 左側 9.6 まで改善した。さらに, 2 年後, 右 側 9.9, 左側 9.2 まで低下した。左側に関しては, 治療 前の数值より改善し，ほぼ正常值まで回復した。同時 に, サーモグラフィー検査による足先, 指先の体表面 温度に明らかな改善が認められた。

症例 3:84 歳女性 (身長 $141 \mathrm{~cm}$, 体重 $35 \mathrm{~kg}$ )。主訴 は頻尿. 八味地黄丸 TJ-7 (7.5 g/日) 投与後 1 力月, 工 コー画像で膀胱径が著明に減少し, 残尿が $335.7 \mathrm{ml}$ か ら平均 $177 \mathrm{ml}$ に減少した。

\section{5. 動脈硬化}

CAVI や PWV は動脈硬化の指標であるが, これらは 年齢とともに一定の相関関係をもって動脈硬化が進行 する．PWVを改善させる薬剤として，アンジオテンシ ン受容体拮抗薬 $(\mathrm{ARB})$, varsartan, telmisartan $(16,17)$ の報告がある。CAVIに関しては cardesartan と olmesartan $(18,19)$ が改善することが分かっている. スタチン剤は脳梗塞や心循環器疾患の発生頻度を低下 させるが(20), PWV の改善については分からない.

降圧剂やスタチン剂の影響を否定できないが，八味 地黄丸が CAVI 改善に中心的な役割を果たしていた ものと考えてもよい．また，血行動態の改善によって 利尿効果が奏功し, 膀胱径と残尿が減少した。ARB による PWVや CAVI 改善には, ARB がもつ抗酸化 作用 (19) や PPAR- $\gamma$ (peroxisome proliferative-activated receptor- $\gamma$ ) を介した血管壁に扔ける抗炎症作用 (15) などが，動脈硬化の進展を抑制しているものと考えら れている. 我々の基礎研究で, 六味丸と比較して, 八 味地黄丸は高齢ラットにも, より強い弛緩作用を表し た。八味地黄丸にも抗酸化作用があり (16), このよう な薬理作用がCAVIの改善に貢献していると推測される.

漢方薬は多成分複合薬であるので, 個々の生薬やそ の中に含有する多種の有効成分フィトケミカルの多種 多様な作用点・機序を有している $(2,10,21)$ 。それぞ れの受容体, イオンチャネル, 細胞内情報伝達系への
多彩な作用は複雑な薬理学的相互作用によって, 総括 的に生体内・外で効果を表す，高齢者（老人症候群） の慢性疾患では，例えば利尿剂などの投与量の調節 (減量)を強いられるケースでも, 利水剂 (漢方薬) が 相補・代替医療として重要な役割を果たせる $(2,20)$. 慢性疾患の治療で複数の西洋治療薬での効果が不十分 である場合や副作用の問題などの場合に，本症例のよ うに漢方薬の併用療法や代替療法で治療効果が十分に 期待される場合も多い.

\section{6. おわりに}

「腎」は生体エネルギーを表す。補腎剤は血管内皮 性と平滑筋作用による強力な血管弛緩作用を示す。し かし，血管内皮に関連する機能は加齢とともに減弱す る.八味地黄丸は加齢依存性弛緩作用を維持した。 添 加された含有生薬による複雑な相互作用によると考え られる。しかし，糖尿病病態ラットでは血管弛緩作用 の加齢変化は著明でなかった．まとめると，(1)多種構 成生薬からなる漢方薬 (複合多成分) の効果は加齢変 化を受けにくい. (2)老年症候群（多臓器疾患）に高い 有効性がある. (3)高齢者の恒常性維持に貢献できる. (4)補腎剂は抗加齢効果が期待できる. 動脈硬化指標 （CAVI）を改善した。（5)慢性疾患には, 補腎剂の臨床 的効果発現は急性投与では難しく, 長期投与が必要で ある。

著者の利益相反：開示すべき利益相反はない.

\section{文献}

1) 水野修一. 漢方薬理学. メディカルユーコン; 2007.

2) 佐藤廣康. 日薬理誌. 2008;132:260-264.

3) 寺澤捷年. EBM 漢方. 医歯薬出版; 2003 .

4) 吉田途男. 日東医誌. 1979;29:175-182.

5）城石平一,他. 和漢医薬学会. 1985;2:144-145.

6) 吉田宏二郎, 他. 基礎と臨床. 1991;9:2861-2870.

7) Nishida S, et al. J Integrative Med Ther. 2015;2:6-11.

8) Satoh H, et al. Chap 1. Res Signpost. Kerala; 2010.

9) Satoh H. J Integr Med. 2013;11:11-16.

10) 西田清一郎, 他. 日東医誌. 2012;63:109-115.

11) Hayashi G, et al. Med Electr Biol Enfin. 1975;13:293-297.

12) Shirai L, et al. J Atheroscler Thromb. 2006;13:101-107.

13) Halperin JL. Thromb Res. 2002;106:303-311.

14) Satoh H. J Acupunct Meridian Stud. 2009;2:130-134.

15) 佐藤廣康. 日薬理誌. 2014;143:56-60.

16) Jung AD. Kor Circ J. 2009;39:180-184.

17) Karalliedde J, et al. Hypertension. 2008;51:1617-1623.

18) Miyashita Y, et al. J Atheroscler Thromb. 2009;16;621-626.

19) Bokuda K, et al. Vasc Health Risk Manag. 2010;6:571-578.

20) Paciaroni M, et al. Expert Rev Cardiovasc Ther. 2009;7:12311243.

21) Satoh H. J Intercult Ethnopharmacol. 2014;3:196-200. 